\title{
Pemberdayaan Petani Jeruk Melalui Badan Usaha Milik Desa Untuk Meningkatkan Pendapatan Masyarakat Desa Sumbersekar, Kecamatan Dau, Kabupaten Malang
}

\author{
Empowerment of Orange Farmers through Village Owned Enterprises to Increase the Income of \\ the People of Sumbersekar Village, Dau District, Malang Regency
}

\author{
Zainol Arifin ${ }^{1 *}$, Cahyo Sasmito ${ }^{2}$, Cakti Indra Gunawana ${ }^{3}$ \\ ${ }^{1}$ Program Studi Agribisnis, Universitas Tribhuwana Tunggadewi \\ 2 Program Studi Administrasi Publik, Universitas Tribhuwana Tunggadewi \\ ${ }^{3}$ Program Studi Manajemen, Universitas Tribhuwana Tunggadewi \\ *dr.zainolarifin@gmail.com
}

\begin{abstract}
ABSTRAK
Sebagai penopang pendapatan asli desa Sumbersekar, untuk meningkatkan asli pendapatan desa Sumbersekar Dau Malang, maka tuntutan ke depan adalah membayar pajak desa sesuai dengan ketentuan. Untuk itu sebagai masyarakat petani umumnya Desa Sumbersekar memiliki potensi antara lain, padi, jagung, singkong, dan Jeruk merupakan hal yang perlu ditingkatkan produksinya. Pelatihan Manajemen Badan Usaha Milik Desa (BUMDES) : Manajemen SDM dalam hal perencanaan, pengorganisasian, pemahaman dan pendefinisian terhadap kerja sehingga masing-masing divisi memahami tugas dan fungsinya serta dapat meningkatkan kinerja dari divisi. Selain itu, dalam hal perencanaan program kerja perlu diberikan pembinaan tentang pembuatan program kerja yang terjadwal sehingga program kerja menjadi lebih terarah dan dapat meningkatkan kinerja daripada Badan usaha Milik Desa. Manajemen keuangan, dalam hal pembukuan atau pencatatan transaksi keuangan sehingga mereka dapat mengetahui berapa besarnya pemasukan dan pengeluaran setiap musimnya, dengan pembuatan jurnal sederhana untuk mencatat setiap transaksi keuangan, maka dapat membentuk arus kas serta melakukan analisis terhadap arus kas untuk setiap musimnya, sehingga dapat menjadi pedoman atau acuan bagi usaha masyarakat dan petani jeruk dalam hal perencanaan keuangan sehingga hutang atau pinjaman yang tidak terduga dapat diminimalisir. Pelatihan Model Pemberdayaan Petani Jeruk, Cara Pemupukan, dan Panen, serta penyimpanan yang baik dan benar. Pelatihan teknologi budidaya tanaman Jeruk sesuai dengan standar good agricultural practice (GAP). Untuk meningkatkan kualitas dan kuantitas bahan baku yang dipakai sebagai sari jeruk. Pelatihan pemanfaatan teknologi tepat guna. Ke depan BUMDES pada tanaman Jeruk akan mampu memasarkan dan menjual produk mereka tanpa dibatasi oleh waktu dan tempat, sehingga akan mempercepat perkembangan usaha dan meningkatkan kesejahteraan usaha masyarakat petani jeruk.
\end{abstract}

Kata kunci - badan usaha, pemberdayaan, petani jeruk

\begin{abstract}
village, the future demand is to pay village tax in accordance with the provisions. Therefore, as a community of farmers, sumbersekar village generally has the potential, among others, rice, corn, cassava, and oranges are things that need to be increased production.Village Owned Enterprise Management Training (BUMDES): HR Management in terms of planning, organizing, understanding and defining the work so that each division understands its duties and functions and can improve the performance of the division. In addition, in terms of work program planning needs to be given guidance on the creation of scheduled work programs so that the work program becomes more targeted and can improve the performance of village-owned enterprises. Financial management, in terms of bookkeeping or recording of financial transactions so that they can find out how much income and expenditure each season, by creating a simple journal to record each financial transaction, it can form cash flow and conduct an analysis of cash flow for each season, so that it can be a guideline or reference for community businesses and citrus farmers in terms of financial planning so that unexpected debts or loans can be minimized. Training model of Empowerment of Citrus Farmers, How to Fertilize, and Harvest, as well as good and correct storage. Citrus cultivation technology training in accordance with good agricultural practice (GAP) standards. To improve the quality and quantity of raw materials used as orange juice.Appropriate technology utilization training. In the future BUMDES on Citrus crops will be able to market and sell their products without being limited by time and place, so that it will accelerate business development and improve the business welfare of citrus farmers.
\end{abstract}

Keywords - business entity, empowerment, citrus farmers 


\section{Pendahuluan}

Secara geografis desa Sumbersekar Kecamatan Dau Kabupaten Malang, merupakan sentra komoditi Jeruk. Sebagian besar penduduk tersebut bermata pencaharian agraris. Di samping juga memiliki usaha sampingan yakni berdagang dan berjualan. Untuk menjamin kelangsungan hidupnya budidaya tanaman alternatif sebagai komoditas unggulan yakni Jeruk. Sebagai penopang pendapatan asli desa Sumbersekar, untuk meningkatkan asli pendapatan desa Sumbersekar Dau Malang, maka tuntutan ke depan adalah membayar pajak desa sesuai dengan ketentuan. Untuk itu sebagai masyarakat petani umumnya Desa Sumbersekar memiliki potensi antara lain, padi, jagung, singkong, dan Jeruk merupakan hal yang perlu ditingkatkan produksinya.

Dengan kondisi yang demikian, tepatlah bila kelompok masyarakat membentuk sebagai badan usaha milik desa yang dinamakan BUMDES untuk menopang perekonomian di Desa tersebut. Dengan prinsip manajemen pengelolaan yang berlandaskan perencanaan, pengorganisasian, pengaktualisasian, dan Kontrol. Untuk menguubah pola sedemikian rupa haruslah hadir teknologi yang hadir di tengah-tengan masyarakat untuk memberikan kontribusi sebagai pendukung utama untuk melakukan aktivitasnya.

Dengan kondisi yang perlu perhatian serius oleh berbagai pihak baik dari Pemerintah maupun dari pihak swasta, Jeruk perlu adanya suatu konsep pendekatan pada masyarakat melalui petani jeruk pengembangan yang terorganisir. Melalui kegiatan ini nantinya pengolahan akan lebih baik dari semula hanya dengan konvensional menjadi profesional.

\section{Target dan Luaran}

a. Alur dan Mekanisme Badan usaha Milik Desa sebagai strategi penciptaan model utama bagi Usaha masyarakat [Desa Sumbersekar Kecamatan Dau Malang].

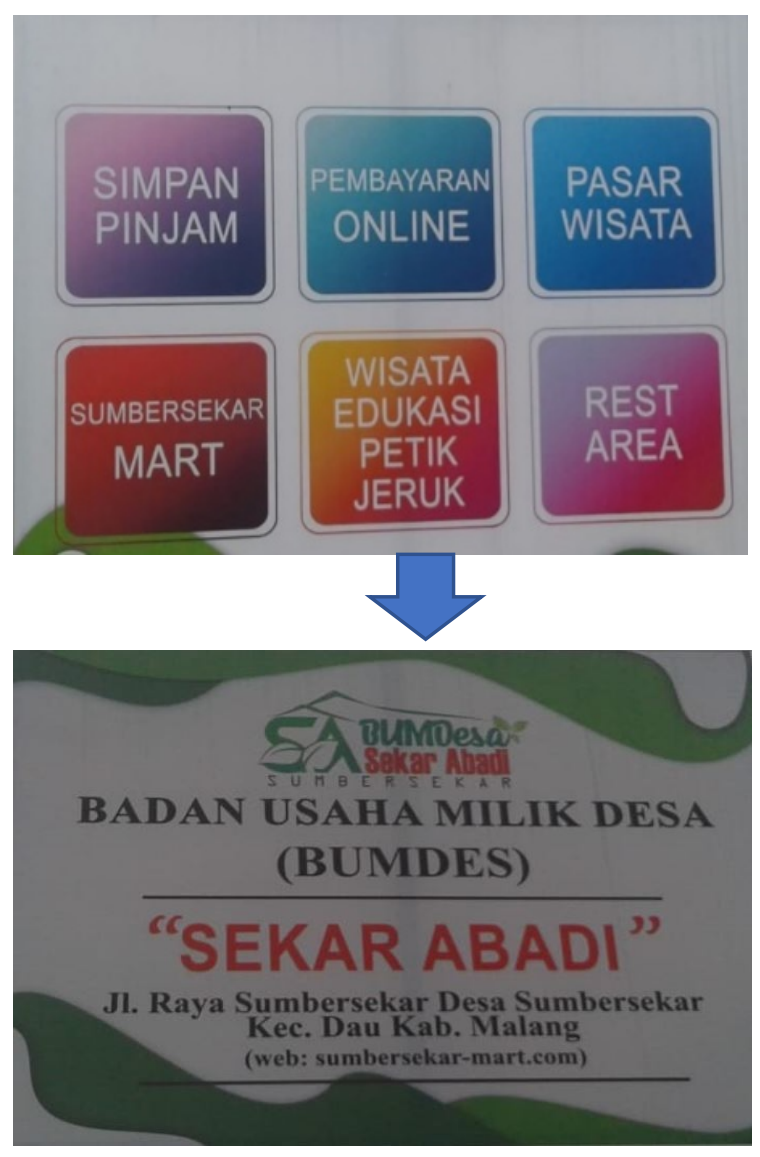

Target Luaran Menjadi produk Bumdes unggulan yang siap pakai dan siap dijual ke pasar Nasional maupun Internasional.

b. Pendidikan dan Pelatihan Manajemen SDM dan keuangan sebagai transfer pengetahuan untuk mengoptimalkan sumber daya manusia dan pengaturan keuangan keluarga dan usaha.

- Manajemen SDM dalam hal perencanaan, pengorganisasian, pemahaman dan pendefinisian terhadap kerja (job description) sehingga masing-masing divisi memahami tugas dan fungsinya serta dapat meningkatkan kinerja dari divisi. Selain itu, dalam hal perencanaan program kerja perlu diberikan pembinaan tentang pembuatan program kerja yang terjadwal (time scheduling) sehingga program kerja menjadi lebih terarah dan dapat meningkatkan kinerja daripada anggota kelompok.

- Manajemen keuangan, dalam hal pembukuan atau pencatatan transaksi keuangan sehingga mereka dapat mengetahui berapa besarnya pemasukan dan pengeluaran setiap musimnya, dengan 
pembuatan jurnal sederhana untuk mencatat setiap transaksi keuangan, maka dapat membentuk arus kas serta melakukan analisis terhadap arus kas (Cash Flow Analysis) untuk setiap pengaturan Bumdes sehingga dapat menjadi pedoman atau acuan bagi kelompok Bumdes Komoditi Jeruk Sumbersekar dalam hal perencanaan keuangan sehingga hutang atau pinjaman yang tidak terduga dapat diminimalkan.

\section{Metodologi}

Berdasarkan beberapa hasil diskusi dan kajian tentang permasalahan diatas, maka ada beberapa solusi yang ditawarkan sebagai berikut:

a. Pelatihan Manajemen Badan Usaha Desa (BUMDES) :

- Manajemen SDM dalam hal perencanaan, pengorganisasian, pemahaman dan pendefinisian terhadap kerja sehingga masing-masing divisi memahami tugas dan fungsinya serta dapat meningkatkan kinerja dari divisi. Selain itu, dalam hal perencanaan program kerja perlu diberikan pembinaan tentang pembuatan program kerja yang terjadwal sehingga program kerja menjadi lebih terarah dan dapat meningkatkan kinerja daripada Badan usaha Desa.

- Manajemen keuangan, dalam hal pembukuan atau pencatatan transaksi keuangan sehingga mereka dapat mengetahui berapa besarnya pemasukan dan pengeluaran setiap musimnya, dengan pembuatan jurnal sederhana untuk mencatat setiap transaksi keuangan, maka dapat membentuk arus kas serta melakukan analisis terhadap arus kas untuk setiap musimnya, sehingga dapat menjadi pedoman atau acuan bagi usaha masyarakat sari jambu air dalam hal perencanaan keuangan sehingga hutang atau pinjaman yang tidak terduga dapat diminimalkan.

b. Pelatihan Model Pemberdayaan Petani Jeruk, Cara Pemupukan, dan Panen, serta penyimpanan yang baik dan benar. c. Pelatihan teknologi budidaya tanaman Jeruk sesuai dengan standar good agricultural practice (GAP). Untuk meningkatkan kualitas dan kuantitas bahan baku yang dipakai sebagai sari jeruk.

d. Pelatihan pemanfaatan teknologi tepat guna. Ke depan BUMDES pada tanaman Jeruk akan mampu mempromosikan dan menjual produk mereka tanpa dibatasi oleh waktu dan tempat, sehingga akan mempercepat perkembangan usaha dan meningkatkan kesejahteraan usaha masyarakat petani jeruk.

\section{Pembahasan}

Sesuai dengan target dan luaran program Pengabdian Masyarakat telah banyak yang sudah dicapai bagi Pemberdayaan petani jeruk Desa Sumbersekar Dau Malang bersama Bumdes, Targer dan luaran program tercantum pada tabel 1.

Adapun rata-rata hasil yang dicapai oleh tim pengabdi sebagai berikut :

$$
\begin{aligned}
\% \text { Capaian } & =\frac{\text { Capaian I }+ \text { Capaian II }+ \text { Capaian III }}{3} \times 100 \% \\
& =\frac{88 \%+85 \%+60 \%}{3} \times 100 \% \\
& =77,6 \%(\mathrm{BAIK})
\end{aligned}
$$

\subsection{Permasalahan 1, Kegiatan Pengabdian} yang telah dilaksanakan dan capaian Kegiatan.

Kelompok masyarakat petani jeruk masih begitu banyak kekurangan bahan yang perlu dilakukan oleh pihak pengusaha lokal. Seiring berjalannya waktu yang permintaan pasar, baik lokal maupun nasional. Bahwa jamu tradisional yang ada semakin kesulitan bahan baku. Maka untuk pengembangan bahan tersebut tidak diperlukan impor bahan dari luar. Akan tetapi untuk meningkatkan rasa yang lebih baik. Kelompok petani jeruk sebagian besar menggunakan bahan lokal desa Sumbersekar Dau Malang.

Berdasarkan permasalahan di atas, maka kami melaksanakan kegiatan pengabdian melalui program kegiatan pengabdi sebagai upaya memberikan solusi terhadap permasalahan diatas yaitu memberikan pelatihan ketrampilan . Ketrampilan yang diberikan akan memotivasi 
kelompok pembuat varian dapat meningkatkan pendapatan keluarga sekaligus mendapatkan nilai tambah bagi masyarakat yang ada di sekitar pengembang kelompok pemberdayaan petani jeruk.

Di samping itu pula, pelatihan keterampilan petani jeruk diharapkan masyarakat dapat meningkatkan ketrampilan dan keahlian. Mengingat selama ini cara meracik bahan-bahan tersebut masih tergantung pada kebiasaan masyarakat dan sifatnya turun temurun oleh nenek moyang.

Tabel 1. Pencapaian Hasil Pengabdian Masyarakat

\begin{tabular}{|c|c|c|c|}
\hline No & Nama Kegiatan & Target & Capaian \\
\hline 1. & $\begin{array}{l}\text { Pelatihan } \\
\text { Pemberdayaan } \\
\text { Petani Jeruk }\end{array}$ & $\begin{array}{l}\text { Manfaat pelatihan } \\
\text { Menjadikan Minuman } \\
\text { Pengembangan Kawasan } \\
\text { Agrowisata }\end{array}$ & $\begin{array}{l}\text { - Capaian target dari pelatihan ini mencapai } 80 \% \text {, hal } \\
\text { ini dilihat dari produk, yang dihasilkan setelah } \\
\text { pelatihan sangat bervariasi sekali di antara beberapa } \\
\text { kelompok tersebu;. } \\
\text { - Tidak tercapainya kepada target disebabkan beberapa } \\
\text { faktor, terutama adalah keterbatasan waktu yang } \\
\text { dimiliki untuk pelatihan; } \\
\text { - Solusi untuk mengatasi hal tersebut tim IbM telah } \\
\text { melakukan jadwal konsultasi dan pendampingan } \\
\text { setiap hari minggu dengan para pakar. }\end{array}$ \\
\hline 2. & $\begin{array}{l}\text { Pelatihan } \\
\text { Manajemen SDM } \\
\text { dan Keuangan }\end{array}$ & $\begin{array}{l}\text { Memahami cara disiplin, } \\
\text { inovasi dan kreatif } \\
\text { Memahami akuntansi dan } \\
\text { pembukuan sederhana } \\
\text { untuk menjalankan usaha. }\end{array}$ & $\begin{array}{l}\text { - Capaian target dari pelatihan ini mencapai } 75 \% \text {, hal } \\
\text { ini dilihat dari tingkat pendidikan dan keseriusan di } \\
\text { antara beberapa kelompok tersebut; } \\
\text { - Tidak tercapainya kepada target disebabkan beberapa } \\
\text { faktor, terutama adalah tingkat pendidikan yang } \\
\text { rendah dan cenderung malas untuk berpikir dan } \\
\text { mendengarkan; } \\
\text { - Solusi untuk mengatasi hal tersebut tim abdimas telah } \\
\text { melakukan jadwal konsultasi dan pendampingan } \\
\text { setiap hari minggu dengan para pakar. }\end{array}$ \\
\hline 3. & $\begin{array}{l}\text { Pembuatan Model } \\
\text { Bumdes dan } \\
\text { Pelatihan }\end{array}$ & $\begin{array}{l}\text { Terwujudnya Bumdes } \\
\text { untuk desa dan kelompok; } \\
\text { Mampu menjalankan usaha } \\
\text { dan pembinaan jika ada } \\
\text { kesalahan. }\end{array}$ & $\begin{array}{l}\text { - Capaian target dari pelatihan ini mencapai } 75 \% \text {, hal } \\
\text { ini dilihat dari kemampuan administrasi dari } \\
\text { kelompok tersebut dalam mengelola Bumdes; } \\
\text { - Tidak tercapainya kepada target } 100 \% \text {, disebabkan } \\
\text { beberapa faktor, terutama adalah keterampilan dan } \\
\text { pengetahuan mereka yang terbatas; } \\
\text { - Solusi untuk mengatasi hal tersebut tim pengabdi } \\
\text { telah melakukan jadwal konsultasi dan pendampingan } \\
\text { setiap hari minggu dan libur dengan para pakar. }\end{array}$ \\
\hline
\end{tabular}


Tabel 2. Umpan Balik (Feed Back) Kegiatan Pengabdian Masyarakat Bagi Pemberdayaan Petani Jeruk

\section{No VARIABEL UMPAN BALIK}

SKALA PENILAIAN

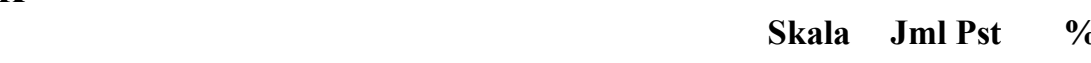

\begin{tabular}{|c|c|c|c|c|}
\hline \multicolumn{5}{|c|}{ A. MATERI } \\
\hline \multirow[t]{5}{*}{1} & \multirow{5}{*}{$\begin{array}{l}\text { Materi Pemberdayaan "Pelatihan Keterampilan Petani Jeruk untuk } \\
\text { menciptakan mata Pencaharian alternatif bagi masyarakat petani }\end{array}$} & Tidak Penting & 0 & 0 \\
\hline & & Kurang Penting & 0 & 0 \\
\hline & & Penting & 13 & 38,24 \\
\hline & & Sangat Penting & 21 & 61,76 \\
\hline & & Total & 34 & 100 \\
\hline \multirow[t]{5}{*}{2} & \multirow{5}{*}{$\begin{array}{l}\text { Materi Pemberdayaan "Pelatihan Manajemen Pengelolaan Usaha } \\
\text { Kecil Aspek Keuangan dan SDM }\end{array}$} & Tidak Penting & 0 & 0 \\
\hline & & Kurang Penting & 0 & 0 \\
\hline & & Penting & 17 & 50 \\
\hline & & Sangat Penting & 17 & 50 \\
\hline & & Total & 34 & 100 \\
\hline \multirow[t]{5}{*}{3} & \multirow{5}{*}{$\begin{array}{l}\text { Materi Pemberdayaan "Pelatihan Metode simulasi Menggunakan } \\
\text { Bumdes" }\end{array}$} & Tidak Penting & 0 & 0 \\
\hline & & Kurang Penting & 0 & 0 \\
\hline & & Penting & 17 & 50 \\
\hline & & Sangat Penting & 17 & 50 \\
\hline & & Total & 34 & 100 \\
\hline \multirow[t]{5}{*}{4} & \multirow{5}{*}{$\begin{array}{l}\text { Materi Pemberdayaan bagi Petani Jeruk" terkait dengan topik } \\
\text { Pengabdi }\end{array}$} & Tidak Penting & 0 & 0 \\
\hline & & Kurang Penting & 0 & 0 \\
\hline & & Penting & 17 & 50 \\
\hline & & Sangat Penting & 17 & 50 \\
\hline & & Total & 34 & 100 \\
\hline \multirow[t]{5}{*}{5} & \multirow[t]{5}{*}{ Secara umum, materi Pengabdi disiapkan dengan baik } & Tidak Penting & 0 & 0 \\
\hline & & Kurang Penting & 0 & 0 \\
\hline & & Penting & 25 & 61,76 \\
\hline & & Sangat Penting & 9 & 38,24 \\
\hline & & Total & 34 & 100 \\
\hline \multirow[t]{5}{*}{6} & \multirow[t]{5}{*}{ Secara umum, materi Pengabdi dapat dimanfaatkan oleh peserta } & Tidak Penting & 0 & 0 \\
\hline & & Kurang Penting & 0 & 0 \\
\hline & & Penting & 21 & 50 \\
\hline & & Sangat Penting & 13 & 50 \\
\hline & & Total & 34 & 100 \\
\hline \multirow[t]{5}{*}{7} & \multirow{5}{*}{$\begin{array}{l}\text { Secara umum, materi pengabdi dapat membantu pengembangan } \\
\text { kelompok }\end{array}$} & Tidak Penting & 0 & 0 \\
\hline & & Kurang Penting & 0 & 0 \\
\hline & & Penting & 13 & 38,24 \\
\hline & & Sangat Penting & 21 & 61,76 \\
\hline & & Total & 34 & 100 \\
\hline
\end{tabular}




\subsection{Permasalahan 2, Kegiatan Pengabdian yang telah dilaksanakan dan Capaian Kegiatan}

Permasalahan yang dihadapi oleh kelompok pertani jeruk yaitu struktur organisasi yang terdapat pada Bumdes sangat sederhana. Walaupun sudah ada beberapa divisi dan staf, tapi masih mengalami hambatan dan tumpang tindih antar pekerjaan. Mengingat kadang pekerjaan satu dikerjakan oleh staf yang lain artinya mengalami job/kerja ganda. Sehingga tidak maksimal. Akan tetapi di home industri jamu tersebut kadang ketua merangkap dalam pekerjaan yang lain, tetapi tetap dapat dikerjakan. Untuk itu, dalam dunia usaha dan dunia industri yang dilakukan oleh kegiatan kelompok ini masih rendahnya tingkat pendidikan, terutama cara berpikir tiap-tiap anggota yang mana usaha tersebut dalam bekerja masih bersifat kebutuhan keluarga dan bersifat konvensional.

Berdasarkan uraian diatas, maka kami melakukan kegiatan pengabdian melalui program pengabdi yakni memberikan tambahan pendidikan melalui pelatihan dan manajemen sumber daya manusia (Human Resources) untuk dapat membekali dan memotivasi kelompok dalam rangka mengembangkan karakter dan prinsip.

Pendidikan dan pelatihan manajemen sumber daya manusia yang dimaksud rasa keingintahuan anggota kelompok petani Jeruk . Dengan tujuan partisipasi aktif dalam pelatihan tersebut. Hal ini jika kelompok petani Jeruk bertanya dalam arti umpan balik maka nara sumber yang kita paparkan akan dapat terjawab dan diterima oleh peserta. Dari jumlah peserta pelatihan dan manajemen sumber daya manusia yang hadir yang sangat penting $60 \%$ sebanyak 16 orang. Dan $40 \%$ orang sebanyak peserta tang menyatakan penting terhadap materi.

Setelah dilaksanakannya pelatihan manajemen sumber daya manusia, anggota petani jeruk mudah memahami dan menerapkan tugas dan tanggung jawab masing-masing sesuai dengan pembagian tugas sebagaimana susunan organisasi yang ada. Di samping itu, kinerja anggota kelompok petani jeruk ini akan meningkat. Hal ini diketahui dengan tidak tumpang tindihnya pekerjaan baik fungsi maupun divisi.

Setiap kegiatan yang dilakukan divisi membuat rencana program kegiatan baik mingguan maupun bulanan sebagai bentuk tugas dan tanggung jawab menjadi lebih baik dan terarah. Hal ini menunjukkan kualitas sumber daya manusia ada peningkatan kualitas . Sebagai gambaran dokumentasi kegiatan pelatihan sumber daya manusia dapat dilihat pada tabel. Dokumen-dokumen pelaksanaan kegiatan IbM pendidikan dan pelatihan manajemen sumber daya manusia.

Berdasarkan tabel 2. Dapat dilihat bahwa sebagian besar anggota kelompok petani jeruk yaitu sebanyak 23 orang atau sebesar $67,65 \%$ menilai jelas terhadap penyampaian materi oleh pemateri dan sisanya sebanyak 11 orang atau sebesar 32,35\% menilai sangat jelas. Di samping itu dari tabel 8. Juga dapat diketahui bahwa sebanyak 28 orang atau sebesar $82,35 \%$ menilai pemateri telah memanfaatkan waktu sesuai dengan jadwal yang diberikan. Sedangkan sisanya sebanyak 6 orang atau sebesar $17,65 \%$ menilai sangat setuju terhadap pemateri yang telah memanfaatkan waktu sesuai jadwal yang diberikan

Pada tabel 3 juga menunjukkan bahwa sebanyak 20 orang anggota kelompok petani jeruk atau sebesar $70 \%$ menilai setuju pemateri menguasai materi yang disampaikan dan sisanya sebanyak 12 orang atau sebesar 30\% sangat setuju terhadap pemateri yang menguasai materi yang disampaikan. Sedangkan terhadap media yang digunakan dalam menyampaikan materi, sebanyak 20 orang atau sebanyak $60 \%$ menilai bahwa media yang digunakan baik dan sisanya sebanyak 7 orang atau sebesar $40 \%$ menilai bahwa media yang digunakan sangat baik.

Secara keseluruhan, feed back anggota kelompok petani Jeruk terhadap pemateri dapat disampaikan sangat baik. Hal ini dapat tercapai karena pemateri yang kompeten dengan materimateri pelatihan selama dilaksanakan pengabdi.

Berdasarkan tabel 4 dapat diketahui bahwa sebanyak 33 orang anggota kelompok petani jeruk sebesar 90\% menyatakan bahwa ruang dan tempat yang dipergunakan nyaman dan sisanya 1 orang atau $10 \%$ juga menyatakan sangat penting terhadap ruang dan tempat yang dipergunakan. Tabel tersebut juga menunjukkan bahwa 
sebanyak 12 orang atau sebesar 4,86\% menyatakan puas terhadap konsumsi yang diberikan selama pelaksanaan program pengabdi dan sisanya 2 orang atau sebesar $4,88 \%$ menyatakan sangat puas terhadap konsumsi yang diberikan selama program pengabdi.

Secara umum, umpan balik terhadap ruangan dan tempat yang dipergunakan dan konsumsi yang disajikan dalam pelaksanaan program pengabdi dapat disimpulkan memuaskan. Hal ini didasarkan bahwa tempat dan akomodasi merupakan salah satu indikator yang dapat mendukung lancarnya pelaksanaan pengabdi ini.

Sehingga dalam pelaksanaan kegiatan dipandang perlu meningkatkan kualitas tempat dan konsumsi selama pelaksanaan program kegiatan pengabdi.

Tabel 3. Umpan balik Terhadap Pemateri

\begin{tabular}{|c|c|c|c|c|}
\hline \multirow[b]{2}{*}{ No } & \multirow{2}{*}{$\begin{array}{l}\text { Variabel } \\
\text { Umpan Balik }\end{array}$} & \multicolumn{3}{|c|}{ Skala Penilaian } \\
\hline & & Skala & $\begin{array}{c}\text { Jml } \\
\text { Pst }\end{array}$ & $\%$ \\
\hline
\end{tabular}

B. PEMATERI

\begin{tabular}{|c|c|c|c|c|}
\hline \multirow[t]{5}{*}{1} & \multirow{5}{*}{$\begin{array}{l}\text { Secara umum, } \\
\text { PENYAMPAIAN } \\
\text { materi oleh } \\
\text { pemateri }\end{array}$} & Tidak Penting & 0 & 0 \\
\hline & & Kurang Penting & 0 & 0 \\
\hline & & Penting & 23 & 67,65 \\
\hline & & Sangat Penting & 11 & 32.55 \\
\hline & & Total & 34 & 100 \\
\hline \multirow[t]{5}{*}{2} & \multirow{5}{*}{$\begin{array}{l}\text { Secara umum, } \\
\text { pemateri } \\
\text { memanfaatkan } \\
\text { waktu sesuai } \\
\text { dengan jadwal } \\
\text { yang diberikan }\end{array}$} & Tidak Penting & 0 & 0 \\
\hline & & Kurang Penting & 0 & 0 \\
\hline & & Penting & 18 & 62,35 \\
\hline & & Sangat Penting & 6 & 17,65 \\
\hline & & Total & 34 & 100 \\
\hline \multirow[t]{5}{*}{3} & \multirow{5}{*}{$\begin{array}{l}\text { Pemateri } \\
\text { menguasai } \\
\text { materi yang } \\
\text { disampaikan }\end{array}$} & Tidak Penting & 0 & 0 \\
\hline & & Kurang Penting & 0 & 0 \\
\hline & & Penting & 21 & 70 \\
\hline & & Sangat Penting & 13 & 30 \\
\hline & & Total & 34 & 100 \\
\hline \multirow[t]{5}{*}{4} & \multirow{5}{*}{$\begin{array}{l}\text { Media yang } \\
\text { digunakan } \\
\text { dalam } \\
\text { menyampaikan } \\
\text { materi }\end{array}$} & Tidak Penting & 0 & 0 \\
\hline & & Kurang Penting & 0 & 0 \\
\hline & & Penting & 25 & 60 \\
\hline & & Sangat Penting & 9 & 40 \\
\hline & & Total & 34 & 100 \\
\hline
\end{tabular}

Tabel 4. Umpan balik terhadap ruangan dan tempat yang digunakan

\begin{tabular}{lrcc}
\hline $\begin{array}{l}\text { Variabel Umpan } \\
\text { Balik }\end{array}$ & Skala & Jmlh & \% \\
\hline Kenyamanan & Tidak Penting & 0 & 0 \\
ruangan yang & Kurang Penting & 0 & 0 \\
digunakan & Penting & 1 & 2,94 \\
& Sangat Penting & 33 & 97,06 \\
& Total & $\mathbf{3 4}$ & $\mathbf{1 0 0}$ \\
\hline Konsumsi yang & Tidak Penting & 0 & 0 \\
diberikan selama & Kurang Penting & 0 & 0 \\
pengabdi di & Penting & 2 & 90 \\
tempat ini & Sangat Penting & 12 & 10 \\
& Total & $\mathbf{3 4}$ & $\mathbf{1 0 0}$ \\
\hline
\end{tabular}

Umpan balik terhadap pemberian rekomendasi terhadap kegiatan pelaksanaan pengabdi dapat dilihat pada tabel 5. Tabel 5 menyajikan bahwa 22 orang peserta petani jeruk atau sebesar 65\%. Direkomendasi kegiatan program pengabdi ini dan sisanya sebanyak 12 orang atau sebesar 35\% sangat direkomendasi terhadap program pengabdi ini,

Tabel 5. Menunjukkan bahwa anggota kelompok home industri jamu tradisional menyatakan alokasi waktu untuk kegiatan pengabdi adalah cukup bahkan perlu ditambah, yaitu sebanyak 26 orang atau sebesar 80\% menyatakan alokasi waktu untuk kegiatan pengabdi adalah cukup. Sedangkan sisanya sebanyak 8 orang atau sebesar $20 \%$ menyatakan alokasi untuk kegiatan pengabdi perlu ditingkatkan.

Kalau kita simpulkan umpan balik terhadap rekomendasi sangat penting. Hal ini ditunjukkan bahwa sebagian besar anggota kelompok petani jeruk menyatakan alokasi waktu untuk kegiatan pengabdi sedang bahkan perlu ditingkatkan. Serta hal ini juga menunjukkan antusias yang sangat tinggi dari kelompok petani jeruk terhadap pelaksanaan program pengabdi. Bahkan sebagian besar anggota kelompok petani jeruk menyarankan agar program kegiatan program pengabdian ini dapat secara kontinu dilaksanakan, mereka sangat butuh adanya pelatihan-pelatihan yang dilaksanakan dalam program selanjutnya. 
Tabel 5. Umpan balik terhadap Pemberian Rekomendasi

\begin{tabular}{llrcc}
\hline No & Variabel & Skala & Jml & (\%) \\
& Umpan Balik & & Pst & \\
\hline 1. & Rekomendasi, & Tidak Penting & 0 & 0 \\
& kegiatan & Kurang Penting & 0 & 0 \\
& pengabdi ini, & Penting & 22 & 65 \\
& untuk kegiatan & Sangat Penting & 12 & 35 \\
& abdimas & & & \\
& berikutnya & & & \\
& & Total & $\mathbf{3 4}$ & $\mathbf{1 0 0}$ \\
\hline 2. & Alokasi waktu & Tidak Penting & 0 & 0 \\
& untuk pengabdi & Kurang Penting & 0 & 0 \\
& berikutnya. & Penting & 26 & 80 \\
& & Sangat Penting & 8 & 20 \\
& & Total & $\mathbf{3 4}$ & $\mathbf{1 0 0}$ \\
\hline
\end{tabular}

\subsection{Permasalahan 3, Kegiatan Pengabdian Yang Telah Dilaksanakan dan Capaian Kegiatan.}

Dalam pencapaian program pengabdi yang dilaksanakan ada kegiatan yang bersifat transfer teknologi budidaya tanaman jeruk Pelatihan teknologi budidaya tanaman jeruk sesuai dengan standar good agricultural practice (GAP). Untuk meningkatkan kualitas dan kuantitas bahan baku yang dipakai sebagai jamu tradisonal. Pelatihan ini dilakukan selama 1 minggu untuk setiap mitra. Dengan menyesuaikan materi pelatihan sesuai dengan potensi sumber daya alam dan kondisi masyarakat. Desa Sumbersekar mempunyai potensi hasil pertanian yang melimpah pada hampir setiap bulan tertentu yang menyebabkan mudah untuk memperoleh bahan baku minuman keluarga. Dari hasil pelatihan rata-rata peserta mendapatkan 75\% merasa Sangat puas. Sedang sisanya 25\% merasa Puas. Dari kesimpulan adanya pelatihan teknologi budidaya diharapkan dapat menguntungkan para petani jeruk yang ada di wilayah Sumbersekar Dau Malang., Sehingga stok bahan baku jeruk tetap berlangsung sesuai standar Good Agricultural Practice (GAP).

\section{Kesimpulan}

Dari kegiatan Pengabdian masyarakat dengan pemberdayaan petani jeruk melalui Bumdes Desa Sumbersekar Kecamatan Dau Kabupaten Malang yang telah dilaksanakan dapat disimpulkan sebagai berikut.

a. Pelatihan Manajemen Badan Usaha Milik Desa (BUMDES) :Manajemen SDM dalam hal perencanaan, pengorganisasian, pemahaman dan pendefinisian terhadap kerja sehingga masing-masing divisi memahami tugas dan fungsinya serta dapat meningkatkan kinerja dari divisi

b. Manajemen keuangan, dalam hal pembukuan atau pencatatan transaksi keuangan sehingga mereka dapat mengetahui berapa besarnya pemasukan dan pengeluaran setiap musimnya.

c. Pelatihan Model Pemberdayaan Petani Jeruk, Cara Pemupukan, dan Panen, serta penyimpanan yang baik dan benar. Pelatihan teknologi budidaya tanaman Jeruk sesuai dengan standar good agricultural practice (GAP)

d. Pelatihan pemanfaatan teknologi tepat guna. Ke depan BUMDES pada tanaman Jeruk akan mampu memasarkan dan menjual produk mereka tanpa dibatasi oleh waktu dan tempat, sehingga akan mempercepat perkembangan usaha dan meningkatkan kesejahteraan usaha masyarakat petani jeruk

\section{Daftar Pustaka}

[1] Altaf, Khan AR, Ali L, B. L. 2008. (2008). Propagation of Rough Lemon (Citrus Jambhiri Lush.) through In vitro Culture and Adventitious Rooting in Cuttings. Electronic Journal of Enviromental Agricultural and Food Chemistry 7, 7, 11.

[2] Ambarwati, A. . (1987). Induksi Kalus dan Differensiasi pada Kultur Jaringan Gnetum gnemon L. Fakultas Biologi. Yogyakarta: Universitas Gadjah Mada.

[3] Basri, Z. (2004). Kultur Jaringan Tanaman. Universitas Tadulako Prees.

[4] Cameiro, L.A., R.F.G. Araujo, G.J.M Brito, M.P.H.P. Fonseca, . Costa, O. J. C. and. E. M. (1999). In Vitro Regeneration from Leaf Explants of Neoregelia cruenla (R. Graham) L.B. Smith, an endemic bromeliad from Eastern Brazil. Plant Cell, Tissue and Organ Cu Lture. 55:79-83. 
[5] Gunawan, L. . (1988). Teknik Kultur Jaringan. Laboratorium Kultur Jaringan Tanaman Pusat Antar Universitas ( PAU ) Biotek. Bogor.

[6] Gunawan, L. . (1995). Teknik Kultur In Vitro Dalam Hortikultura. Jakarta : Penebar Swadaya.

[7] T., D. E. Kester, F. T. D. J. A. R. L. G. (1997). Plant Propagation Principles And Practices Sixth Edition. Prentice Hall Inc,. New Jersey

[8] Imran. (2005). Inisiasi Tunas Tanaman Panili (Vanila planifolia Andrews) pada Berbagai Konsentrasi BAP secara In Vitro. Skripsi. Fakultas Pertanian. Universitas Tadulako. Palu. (Tidak dipublikasikan).

[9] Iser, M., Fettig, S., Scheying, F., Viertel, K., and Hess, D. (1999). Genotype-Dependent Stable Genetic Transformation in Germany Spring Wheat Varieties Selected For High Regeneration Potential. J. Plant Physiol, 154:509-516.

[10] Jajoo, A. (2010). In vitro Propagation of Citrus limonia Osbeck through Nucellar Embryo Culture. Journal of Biological Sciences 2, 2(1): 6-8.

[11] Mukhtar, R., M. M. Khan, B. Fatima, M. A. and A. S. (2005). In Vitro Regeneration and Multiple Shoots Induction in Citrus reticulata (Blanco). International Journal Agri. Biol., Vol. 7, No.

[12] Nisa, C. dan R. (2005). Kultur Jaringan Beberapa Kultivar Buah Pisang (Musa paradisiaca L.) dengan Pemberian Campuran NAA dan Kinetin. Bioscientiae, Volume 2,N, Halaman 23-36.

[13] Sarma C, Borthakur A, Singh S, Modi MK, S. P. (2011). Efficient In vitro Plant Regeneration from Cotyledonary Explants of Citrus reticulata L. Scholars Research. Scholars Research

[14] Sarwono, B. (1995). Jeruk dan Kerabatnya. . Penebar Swadaya.

[15] Statistik, B. P. (2013). Sulawesi Tengah Dalam Angka. Badan Pusat Statistik Propinsi Sulawesi Tengah.

[16] Sukmadjaja D., dan M. I. (2003). Perbanyakan Bibit Jati Melalui Kultur Jaringan. Bogor: Balai Penelitian Bioteknologi dan Sumberdaya Genetik Pertanian.

[17] Takumi, S and Shimada, T. (1997). Variation in Transformation Frequencies Among Six Common Wheat Cultivars Through Particle Bombardment of Scutellar Tissues. Genes Genet. Syst., 72:63-69.

[18] Wardiyati, T. (1998). Kultur Jaringan Tanaman Hortikultura. Lembaga Penelitian Fakultas Pertanian UNIBRAW, Malang. 